\title{
Teaching Pediatric Surgery in The Online Environment
}

\section{Challenges and Opportunities}

\author{
https://doi.org/10.3991/ijoe.v17i05.22051 \\ Anatolii Levitskyi, Iryna Benzar, Volodymyr Vitiaz, \\ Dmytro Golovatiuk ( ${ }^{\bowtie}$ ), Oleksandr Karabenyuk \\ Bogomolets National Medical University, Kyiv, Ukraine \\ dvgolovatukegmail.com
}

\begin{abstract}
The research is aimed at investigating challenges and opportunities of teaching online course in Pediatric Surgery at Bogomolets National Medical University, Kyiv, Ukraine. The participants were 42 students of the 5-th year of study. After taking the course, the students were offered to fill in 24item 4-point Likert-type scale containing the statements regarding various issues of distance learning: gaining theoretical and practical knowledge, teacherstudent and student-student interaction, the interface and content of the course, technical issues and computer literacy, academic success, development of selfdirected learning skills, as well as motivation for learning, critical thinking, problem solving, self-organization and time management skills. The median value for the total cohort is 3 indicating that the majority of students gave affirmative responses. Students positively evaluated the course content and structure, interface of the platform Neuron and the interactive tools like forums, chats, videoconferencing which allowed communicating with peers and the teacher in real time and getting immediate feedback. At the same time, students experience lack of practical skills as quarantine measures don't allow attending face-to-face lessons, they cannot interact with patients and participate in surgical operations, etc. This is a challenging task to develop medical students' motivation, professional problem-solving and critical thinking skills in the online environment. The authors offer the recommendations to enhance the quality of online learning: use image-guided surgical simulation tools, implement interactive forms of virtual teaching, case method.
\end{abstract}

Keywords - Pediatric surgery, medical students, online learning, online platform, course, theoretical knowledge, practical skills, videoconferencing, interaction

\section{Introduction}

\subsection{Problem statement}

COVID-19 pandemic caused transmission of university education to the online format. It was not possible to attend lectures and practical classes, so, all forms of 
learning activities moved to various distance learning platforms, MOOCs, videoconferencing tools etc. This strongly influenced medical education, which is considered to be patient-based education [1]. The risk to transmit virus to patients, or get infected in the hospital was quite high, in addition, in most countries strict quarantine measures were implemented which made impossible any face-to-face interaction. This was a challenge as surgical education is considered to be one of the most complex educational models even before the COVID-19 outbreak [2]. Students should acquire clinical and surgical technical skills and the task is to provide online education to develop these skills in the current conditions.

The recent research works are devoted to advantages and disadvantages of distance surgical education [3-7]. Among the advantages are flexibility, self-paced learning, cost effectiveness, possibility to use innovative interactive online tools. The problem and challenges are limited feedback, lack of interpersonal communication, technical knowledge and poor Internet connection; more theoretical rather than practical skills obtained; online learning requires self-motivation and time management skills. The students are worried that remote learning will influence their ability to develop clinical competence. As stated by Rafi et al. [7], the majority of the students believe that practical classes in medical education cannot be held virtually as patient care cannot be provided using online methods.

The research conducted among Romanian students [8] shows that in the totally online mode the advantages of distant education decrease in value, but more challenges arise. Respondents mention that it is more difficult to study and concentrate on learning material, they feel anxious about presenting seminar projects, expressing opinions in videoconferencing discussions and write in forums. At the same time, students get easily distracted as some of them lack of enough learning space feel isolated, deficiency of interaction between students and teachers, and in general, give less value to online learning comparing to face-to-face learning. These findings are supported by Olum et al. [9], in whose research about a half of respondents believed that e-learning reduces the quality of knowledge attained and is not an efficient method of teaching.

Quadri et al. [10] identify four types of barriers in online learning: at the student, teacher, infrastructure and technology levels, and educational institution management. The biggest challenge in this study was the level of infrastructure and Internet access. The most important factor affecting the successful implementation of technologies is the limited time for the development of teaching aids and their placement on appropriate online platforms, while the level of digital competence of students was the least significant factor. And vice versa, teachers' level of digital competence, and positive experience of using educational technologies in teaching promote their professional self-efficacy, which positively correlates with students' academic success [11].

According to [12], socio-psychological barriers, those related to social interaction, are the most significant among student youth. Students feel isolated, they lack communication with peers and teachers. This problem can be solved by integrating into the learning process: interactivity, collaborative and cooperative learning, individualized learning, multimodal presentation of content and tasks, creating a psychological- 
ly safe environment, providing timely and constructive feedback, monitoring group interaction and dynamics [13].

\subsection{Organization of distance education at the department of pediatric surgery, Bogomolets National Medical University}

In accordance with the decree № 211 of the Cabinet of Ministers of Ukraine "On prevention of the spread of acute respiratory disease COVID-19 caused by coronavirus SARS-CoV-2 on the territory of Ukraine", Bogomolets National Medical University introduced online learning beginning from March, 12, 2020. Education at the Department of Pediatric Surgery in the autumn semester 2020 was provided fully online. All the classes were held according to the curriculum in real time, using videoconferencing tools (Zoom, Google Meet). All the tests and didactic materials were uploaded to the Neuron platform of distance education, developed on the basis of LMS Moodle (Modular Object-Oriented Dynamic Learning Environment). The additional learning platforms recommended for student are MOOCs (Coursera, EdX, Prometheus platforms). Students can communicate with teachers via social networking sites, Viber, Telegram, electronic mail, etc.

The course of Pediatric Surgery is obligatory for 5-th year students of I,II,II and IV Medical departments of the university and has 43 hours of classroom hours (4 lectures and 5 practical classes), and 15 hours of self-work. The purposes of studying pediatric surgery are mastering theoretical and practical knowledge of etiology, pathogenesis, typical and atypical clinical manifestations, diagnostic methods, differential diagnosis, conservative and surgical treatment, and rehabilitation of children with surgical pathology within the relevant training of a general practitioner (pedsurg.com.ua).

\subsection{Online learning tools in medical education}

The literature analysis has shown the effectiveness of implementing Moodle for the students of medical universities. Moodle platform matches such criteria as system features, content support, content creation, user management and reporting system [14]. The platform is considered to be flexible, easy to use and access, promotes collaboration between users via forums, chats, private messaging, universities can use it as an additional method to traditional education, or for exclusively online learning [8; 15]. This is an effective tool for control, monitoring and evaluating the knowledge quality [16]. According to [17], students who used Moodle for self-directed learning are more successful than students who weren't asked to use it. The study [18] shows correlation between students' positive evaluation of Moodle course and high grades. Avramescu [19] believes that online learning platforms and technologies cannot replace face-to-face learning completely, but can significantly improve medical students' skills and knowledge thus making them better prepared for practice and develop self-directed autonomous learning. Peerapolchaikul et al. [20] state that Moodle can be used for the development of students problem-solving skills. 
One of the technologies to provide successful interaction in the online learning environment is using videoconferencing (Zoom, MS Teams, Google Meet). Social presence in real-time online communication is engaging and looks like natural interaction. Three interrelated factors of online videoconferencing comprise cognitive presence (new information, rules, research, ideas, articles; teacher presence (instructions, assessment, class management); social presence: emotions, self-disclosure, group cohesion [21].

Among the benefits of videoconferencing are enhancing communication and collaboration skills [22], the authenticity of interaction and educational materials [23]; possibility of case-presentations which encouraged active students' participation in discussions [24]; development of peer-assessment skills [25]; self-initiated learning in asynchronous mode [26], interactivity, ease of use, engaging learning environment [27].

Surgical telementoring, i.e., real-time interactive teaching of techniques by an expert surgeon to a student not at the same site [28], is widely used among surgeons for telementoring surgical procedures and in trauma and emergency medicine; also, it can be used to care of the patients after surgical operations [29].

The biggest challenge in videoconferencing is the quality of Internet connection [24]. At the same time, using this too requires a high bandwidth communication path to transmit and receive high quality images; free version of the program might have restrictions in time (for example, Zoom interrupts after $40 \mathrm{~min}$.). We should take into account that high-quality and unlimited video-conferencing systems are quite expensive. Also, among the problems are class management, assessment techniques, lack of teachers' confidence and self-efficacy, time-consuming preparation of all materials, students' loss of attention and concentration [27]. According to Rafi et al. [7], the duration of synchronous video lesson should not exceed 45 minutes, this is the optimal time for effective material perception, distribution of attention and ensuring the balance between the psychological and physical health of the student.

This paper aims to determine and analyze the advantages and challenges of teaching Pediatric Surgery in the online mode on the basis student survey results at Bogomolets National Medical University.

\section{Methods}

\subsection{Research design}

The survey was held in the autumn semester 2020, which was aimed at collecting and analyzing students' perceptions on the effectiveness of studying the course "Pediatric Surgery" in the online mode.

This is a quantitative research, which applied a closed-ended 24-item questionnaire, followed by data analysis and interpretation using descriptive statistics. 


\subsection{Participants and ethical issues}

The participants were 42 students of the 5-th year of study, from the Bogomolets National Medical University, Kyiv, Ukraine.

After taking the course "Pediatric Surgery" and taking the exam, the students were offered to fill in the questionnaire in Google Forms on a voluntary basis. The survey was approved by the Research Board of the Department of Pediatric Surgery.

Before the experiment started, students were informed about the nature of experiment, the confidentiality of the observation data, their right to obtain information on the experiment results. The participants could stop the participation at any time without any academic consequences.

\subsection{Data collection and analysis tools}

The survey applied a 24-item Likert-type scale. The first item was multiple choice question on the most effective mode of studying the course: online, blended, face-toface. In questions 2-24 the participants could either strongly disagree, disagree, agree, or strongly agree with the statements regarding various issues of distance learning: gaining theoretical and practical knowledge, teacher-student and student-student interaction, the interface and content of the course, technical issues and computer literacy, academic success, development of self-directed learning skills, as well as motivation for learning, critical thinking, problem solving, self-organization and time management skills. The quantitative data was analyzed using SPSS software.

\section{$3 \quad$ Results and Discussion}

The survey results are presented in Figure 1 and Table 1.

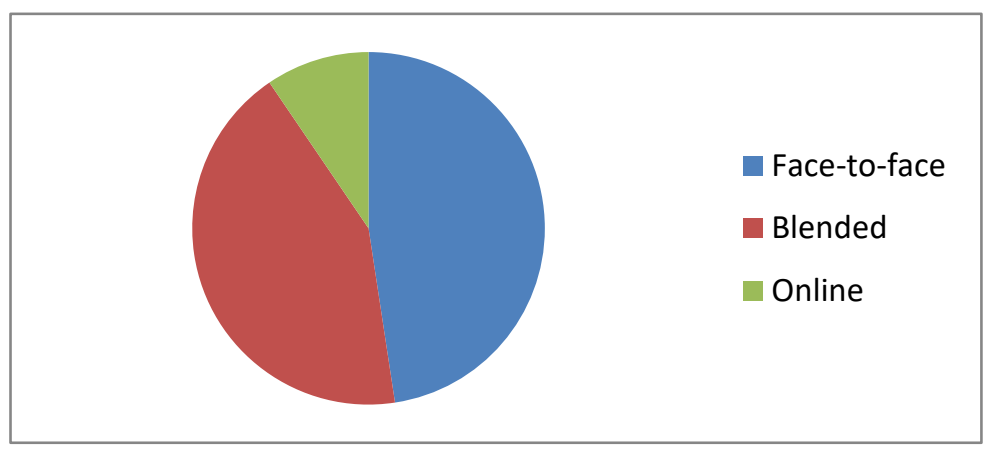

Fig. 1. The most effective mode for studying the course of Pediatric Surgery from medical students' perspective

Answering the first question "In your opinion, what is the most effective mode for studying the course of Pediatric Surgery?", 18 students $(42,9 \%)$ indicated blended learning, $20(47,6 \%)$ face-to-face classes, and only $4(9,5 \%)$ students think that online 
mode is the best one to study Pediatric Surgery. This answer correlates with the statements 1,2, 23 (see Table 1), which are devoted to the quality of gaining theoretical and practical knowledge of Pediatric Surgery. Most students $(80,1 \%)$ agree that they gained enough theoretical knowledge, which is in line with the research conducted by Önöral and Kurtulmus-Yilmaz [30] where most of the students emphasized that online theoretical courses are more advantageous over face-to-face class.

Table 1. Students' perceptions of online learning

\begin{tabular}{|c|c|c|c|c|c|}
\hline Statement & \begin{tabular}{|} 
Strongly \\
disagree \% \\
$(\mathbf{N})$
\end{tabular} & $\begin{array}{c}\text { Disagree \% } \\
(\mathbf{N})\end{array}$ & $\begin{array}{l}\text { Agree \% } \\
(\mathrm{N})\end{array}$ & $\begin{array}{l}\text { Strongly } \\
\text { agree\% } \\
(\mathrm{N})\end{array}$ & Median \\
\hline $\begin{array}{l}\text { 1. I gained enough theoretical knowledge study- } \\
\text { ing the discipline "Pediatric Surgery" online }\end{array}$ & $2,4(1)$ & $16,7(7)$ & $66,8(28)$ & $14,3(6)$ & 3 \\
\hline $\begin{array}{l}\text { 2. I gained enough practical skills in the disci- } \\
\text { pline of "Pediatric Surgery" during distance } \\
\text { learning }\end{array}$ & $47,6(20)$ & 42,9 (18) & $2,4(1)$ & 7,1 (3) & 2 \\
\hline $\begin{array}{l}\text { 3. The Pediatric Surgery course is balanced; I } \\
\text { was not overloaded with information }\end{array}$ & $7,1(3)$ & 4,8 (2) & $19(8)$ & 69,1 (29) & 4 \\
\hline $\begin{array}{l}\text { 4. The course curriculum provides interesting } \\
\text { and informative content }\end{array}$ & $2,4(1)$ & $2,4(1)$ & 45,2 (19) & $50(21)$ & 4 \\
\hline $\begin{array}{l}\text { 5. I fully understood the content of lectures and } \\
\text { assignments }\end{array}$ & - & $4,8(2)$ & $57,1(24)$ & 38,1 (16) & 3 \\
\hline $\begin{array}{l}\text { 6. The Pediatric Surgery course on the Neuron } \\
\text { platform had a user-friendly interface }\end{array}$ & - & $4,8(2)$ & $52,4(22)$ & 42,9 (18) & 3 \\
\hline $\begin{array}{l}\text { 7. The course had interesting presentations and } \\
\text { other multimedia tools }\end{array}$ & $2,4(1)$ & $7,1(3)$ & $23,8(10)$ & 66,7 (28) & 4 \\
\hline $\begin{array}{l}\text { 8. I had the opportunity to communicate in } \\
\text { forums, chats }\end{array}$ & $9,5(4)$ & $14,3(6)$ & $11,9(5)$ & $64,3(27)$ & 4 \\
\hline $\begin{array}{l}\text { 9. I had the opportunity to communicate with } \\
\text { the teacher and group mates in real time during } \\
\text { video conferences }\end{array}$ & $14,3(6)$ & $14,3(6)$ & $9,5(4)$ & $61,9(26)$ & 4 \\
\hline $\begin{array}{l}\text { 10. I had the opportunity to work at my own } \\
\text { pace, choosing a convenient time and place of } \\
\text { work }\end{array}$ & $9,5(4)$ & $4,8(2)$ & $26,2(11)$ & $59,5(25)$ & 4 \\
\hline $\begin{array}{l}\text { 11. I received the feedback from the teacher on } \\
\text { time and in full }\end{array}$ & $7,1(3)$ & 9,5 (4) & 31 (13) & $52,4(22)$ & 4 \\
\hline $\begin{array}{l}\text { 12. I had no difficulty working with the Neuron } \\
\text { system and other technical means offered by the } \\
\text { teacher }\end{array}$ & $2,4(1)$ & $16,7(7)$ & $9,5(4)$ & $71,4(30)$ & 4 \\
\hline $\begin{array}{l}\text { 13. I had no problems with Internet speed or } \\
\text { other technical issues }\end{array}$ & 7,1 (3) & $21,4(9)$ & 33,3 (14) & 38,1 (16) & 3 \\
\hline $\begin{array}{l}\text { 14. Distance learning helps to increase learning } \\
\text { motivation }\end{array}$ & $26,2(11)$ & 35,7 (15) & 31 (13) & $7,1(3)$ & 2 \\
\hline $\begin{array}{l}\text { 15. Distance learning promotes the development } \\
\text { of self-directed learning skills }\end{array}$ & 14,3 (6) & $19(8)$ & $45,2(19)$ & $21,4(9)$ & 3 \\
\hline $\begin{array}{l}\text { 16. Distance learning promotes the development } \\
\text { of self-organization and time management skills }\end{array}$ & $19(8)$ & $9,5(4)$ & $47,6(20)$ & 23,8 (10) & 3 \\
\hline $\begin{array}{l}\text { 17. Distance learning promotes better teacher- } \\
\text { student interaction }\end{array}$ & $26,2(11)$ & $57,1(24)$ & $11,9(5)$ & $4,8(2)$ & 2 \\
\hline $\begin{array}{l}\text { 18. Distance learning promotes better student } \\
\text { interaction with other students }\end{array}$ & $23,8(10)$ & $19(8)$ & $47,6(20)$ & $9,5(4)$ & 3 \\
\hline
\end{tabular}


Paper-Teaching Pediatric Surgery in the Online Environment: Challenges and Opportunities

\begin{tabular}{|l|c|c|c|c|c|}
\hline $\begin{array}{l}\text { 19. Distance learning helps to increase students } \\
\text { success in studying the discipline }\end{array}$ & $23,8(10)$ & $38,1(16)$ & $28,6(12)$ & $9,5(4)$ & 2 \\
\hline $\begin{array}{l}\text { 20. Distance learning promotes the development } \\
\text { of critical thinking }\end{array}$ & $26,1(11)$ & $35,7(15)$ & $33,3(14)$ & $4,8(2)$ & 2 \\
\hline $\begin{array}{l}\text { 21. Distance learning promotes the development } \\
\text { of problem-solving skills in professional situa- } \\
\text { tions }\end{array}$ & $31(13)$ & $50(21)$ & $14,3(6)$ & $4,8(2)$ & 2 \\
\hline $\begin{array}{l}\text { 22. Distance learning helps to improve comput- } \\
\text { er literacy }\end{array}$ & $2,4(1)$ & $11,9(5)$ & $33,3(14)$ & $52,4(22)$ & 4 \\
\hline $\begin{array}{l}\text { 23. Distance learning helps to reduce the gap } \\
\text { between theory and practice }\end{array}$ & $57,1(24)$ & $33,3(14)$ & $7,1(3)$ & $2,4(1)$ & 1 \\
\hline
\end{tabular}

According to our survey results, $90,5 \%$ of students think that distance education cannot give enough practical skills in the field of Pediatric Surgery; the same number of students disagree that online learning helps to reduce the gap between theory and practice. $81 \%$ also don't think that learning from home promotes the development of problem-solving skills in professional situations. This is explained by the fact that Pediatric Surgery course requires students' observations of surgical operations, communication with patients, obtaining basic skills of using surgical instruments as well as participating in simulations, allowing students to get involved in the operations as it was real. All the mentioned activities require face-to-face learning, which explains the fact that over $90 \%$ students think that online course cannot give enough practical skills and would choose classroom or blended learning. According to [31], medical students evaluate the ability to apply knowledge into practice as one of the most important professional qualities. Our results are in line with Alsoufi et al. [2] where it is reported that about $80 \%$ of students think that e-learning cannot be used for clinical aspect. Zheng and Zhu [32] report that less than $10 \%$ of students admitted that online teaching on Surgical Nursing was better than traditional one. Studies $[5 ; 33 ; 34]$ claim that developing students' practical skills in the pandemic times is a challenging task.

At the same time, students, evaluating the course content, claim, that it is balanced, they were not overloaded with information $(88,1 \%)$; the course curriculum provides informative content $(95,2 \%)$; the course had interesting presentations and other multimedia tools $(90,5 \%)$. The feedback from students proves that the chosen multimedia tools, presentations in Zoom, video lectures and the activities suggested by instructors, fully satisfy students' needs regarding the content and structure of the course. Respondents state that online mode gave the opportunity be flexible in choosing the convenient place, time, and pace of work $(85,7 \%)$, which correlates with other studies $(3 ; 18 ; 35 ; 36]$.

The analysis of survey questions regarding technical issues, revealed that the Pediatric Surgery course on the Neuron platform had a user-friendly interface $(95,2 \%$ of students agreed with the statement). Also, about $80 \%$ stated that they had no difficulty working with the Neuron system and other technical means offered by the teacher, which is consistent with other study on teaching Traumatology and Orthopedics course on the same platform [4]. It is important to mention that ease of use is the most important condition for the development of e-learning competence in the EPEC model [37]. Excessively complex interface and difficult-to-use platforms increase students' anxiety and lowers confidence in their abilities. 
Two-thirds of respondents in our survey answered that they didn't have any problems with Internet speed. At the same time, almost 30\% indicated that they experienced some technical problems. Other studies from Ukraine report that about a half of students had problems with the Internet in distance education [18; 27]. 85,7\% respondents state that distance learning helps to improve computer literacy. The importance of computer literacy and digital competences is discussed in multiple works in the field of online learning [38-40].

Teacher-student interaction is important in on-line learning. In planning the curriculum, we took into account that students need communication in real time. That is why we combined activities on the Neuron platform and videoconferencing in Zoom. The results of the survey shows that about $75 \%$ of respondents had the opportunity to interact with teacher and other students in forums, chats in real time and $83 \%$ stated that they received the feedback from the teacher on time and in full. This is in line with [4] and [41] in whose researches the same number of medical students were highly satisfied with the quality of synchronous online classes using videoconferencing tools.

The next block of statements is dedicated to the psychological issues of online learning. Lack of social interaction is considered to be one of the biggest problems of online learning [12]. In our research, less than a half of respondents think distance learning promotes better student interaction with other students; only $16,7 \%$ think that distance learning contributes to better teacher-student interaction. Despite the fact that students could communicate in real time using videoconferencing tools, forums, chats, they lack face-to-face communication, which correlates with the first survey question, where only $10 \%$ students agree that Pediatric Surgery can be studied fully online. This result is in line with Srivastava et al. [42] where it was found that the students' evaluation of online surgical classes was borderline when compared with physical class, although the communication with the teacher was well coordinated.

At the same time, more than two-thirds of respondents agree that distance learning promotes the development of self-organization and time management skills. In asynchronous mode students can choose the convenient time and pace for learning, but it is important to manage time effectively to be a successful learner. Also, $62 \%$ of respondents think that distance learning helps to increase students' success in studying Pediatric Surgery.

Distance mode of learning promotes the development of self-directed learning skills. In our research, almost $90 \%$ of medical students agree on the statement. It is extremely important to develop students' self-directed which are related to life-long learning skills in students in order they become active learners and competent professionals [43-47].

Our research findings indicate that $62 \%$ of learners don't think that distance education increases motivation for learning. From one side, self-directed learning is supported by learning motivation, which correlates with the quality of teacher-student interaction, well-balanced curriculum, and high academic performance [48; 49]. From the other side, we should take into account the external factors, caused by COVID-19 pandemic, like social isolation, the level of anxiety [50], impossibility to attend faceto-face classes and communicate with patients. Learning from home sometimes doesn't create comfortable conditions, students can get distracted and disorganized, get tired from extensive use of gadgets and from increased workload [7; 51]. We think 
that the issue of intrinsic and extrinsic learning motivation in medical students' online learning should be further investigated. This could be the prospect for further research.

Less than a half of respondents, according to the results of our research, agree that distance learning promotes the development of critical thinking skills. As the most effective way of developing critical thinking is to create problem-based environment, where students could collaborate [52], we think that implementing case-method would be appropriate to enhance students' critical thinking skills [53]. The online interactive tools like chat rooms in Zoom could be useful tools in organizing students' collaborative work in real time. But still, this is a challenge in the online environment, while students can enhance clinical analysis ability using online interactive tools, clinical operative skills should be developed in the hospital.

Based on the results obtained from our survey and the literature review on distance learning in surgical education in the conditions of online learning caused by pandemic, we propose the following recommendations for academic and managing staff.

1. Use image-guided surgical simulation tools as surgical skills training, which should be combined with image interpretation training [3].

2. Apply interactive forms of virtual teaching, enabling students to interact with patients from their homes; peer mentoring, aiming at increasing students' knowledge and providing psychological support [54]; surgical telementoring, a real-time interactive teaching of techniques by an expert surgeon to a student [29].

3. Implement case method using videoconferencing interactive tools. It is recommended to form teams of 2-3 students in Zoom session and propose to solve a problem; students are supposed to collaborate in real time and present their solution [4].

\section{Conclusion}

Thus, we have analyzed the students' perceptions of the online course in Pediatric Surgery based on the survey results, which included 24 questions regarding technical, methodological, and psychological issues. The median value for the total cohort is 3 indicating that the majority of students gave affirmative responses. They positively evaluated the course content and structure, interface of the platform Neuron and the interactive tools like forums, chats, videoconferencing which allowed communicating with peers and the teacher in real time and getting immediate feedback. At the same time, students feel lack of practical experience caused by quarantine measures which don't allow attending face-to-face lessons and interact with patients, participate in surgical operations, etc. This is a challenging task to develop medical students' motivation, professional problem-solving and critical thinking skills in the online environment. 


\section{$5 \quad$ References}

[1] Sklar, D.P. (2020). COVID-19: Lessons from the disaster that can improve health professions education. Academic medicine: journal of the Association of American Medical Colleges. https://doi.org/10.1097/acm.0000000000003547

[2] Alsoufi, A., Alsuyihili, A., Msherghi, A., Elhadi, A., Atiyah, H., Ashini, A., et al. (2020). Impact of the COVID-19 pandemic on medical education: medical students' knowledge, attitudes, and practices regarding electronic learning. PLoS ONE 15(11): e0242905. https://doi.org/10.1371/journal.pone.0242905

[3] Vazquez, A.G., Verde, J.M., Dal Mas, F., Palermo, M., Cobianchi, L., Marescaux, J., Gallix, B., Dallemagne, B., Perretta, S., and Gimenez, M.E (2020). Image-guided surgical e-learning in the post-COVID-19 pandemic era: what is next? Journal of Laparoendoscopic \& Advanced Surgical Techniques, 30(9): 993-997.https://doi.org/10.1089/lap.2020.0535

[4] Chornyi, V., \& Vakulych, M. (2020). Specificities of remote teaching of traumatology and orthopedics course to medical students. Revista Romaneasca Pentru Educatie Multidimensionala, 12(2Sup1): 34-40. https://doi.org/10.18662/rrem/12. 2sup1/287

[5] Hau, H.-M., Weitz, J., \& Bork, U. (2020). Impact of the COVID-19 pandemic on student and resident teaching and training in surgical oncology. Journal of Clinical Medicine, 9(11): 3431. https://doi.org/10.3390/jcm9113431

[6] Huddart, D, Hirniak, J, Sethi, R, et al. (2020). MedStudentCovid: How social media is supporting students during COVID-19. Med Educ.14215. https://doi.org/10. $\underline{1111 / \text { medu. } 14215}$

[7] Rafi, A. M., Varghese, P. R., \& Kuttichira, P. (2020). The pedagogical shift during COVID 19 pandemic: online medical education, barriers and perceptions in Central Kerala. Journal of Medical Education and Curricular Development, 7. https://doi.org/10.1177/2382120520951795

[8] Coman, C., Țîru, L.G., Meseșan-Schmitz, L., Carmen Stanciu, C., Maria Cristina Bularca, M.C. (2020). Online teaching and learning in higher education during the Coronavirus pandemic: students' perspective. Sustainability, 12 (24): 10367. https://doi.org/10. 3390/su122410367

[9] Olum, R., Atulinda, L., Kigozi, E., Nassozi, D. R., Mulekwa, A., Bongomin, F., \& Kiguli, S. (2020). Medical education and E-learning during COVID-19 pandemic: awareness, attitudes, preferences, and barriers among undergraduate medicine and nursing students at Makerere University, Uganda. Journal of Medical Education and Curricular Development, 7. https://doi.org/10.1177/2382120520973212

[10] Quadri, N. N., Muhammed, A., Sanober, S., Qureshi, M.R. N., \& Shah, A. (2017). Barriers effecting successful implementation of e-learning in Saudi Arabian universities. International Journal of Emerging Technologies in Learning (iJET), 12(06): 94-107. https://doi.org/10.3991/ijet.v12i06.7003

[11] Saienko, N., Lavrysh, Y., Lukianenko, V. (2020). The impact of educational technologies on university teachers' self-efficacy. International Journal of Learning, Teaching and Educational Research, 19(6): 323-336. https://doi.org/10.26803/ijlter.19.6.19

[12] [12] Bakar,A., Shah, K., and Qingyu, X. (2020). The effect of communication barriers on distance learners' achievements. Revista Argentina de Clínica Psicológica, XXIX (5): 248264. https://doi.org/10.24205/03276716.2020.1027

[13] Racheva, V. (2018). Social aspects of synchronous virtual learning environments. AIP Conference Proceedings 2048, 020032. https://doi.org/10.1063/1.5082050 
[14] Liu, Z., Lomovtseva, N., \& Korobeynikova, E. (2020). Online learning platforms: reconstructing modern higher education. International Journal of Emerging Technologies in Learning (IJET), 15(13): 4-21. https://doi.org/10.3991/ijet.v15i13. 14645

[15] Bi, X., \& Shi, X. (2019). On the effects of computer-assisted teaching on learning results based on blended learning method. International Journal of Emerging Technologies in Learning (IJET), 14(01): 58-70. https://doi.org/10.3991/ijet.v14i01. 9458

[16] Zabolotniaia, M., Cheng, Z., Dorozhkin, E., \& Lyzhin, A. (2020). Use of the LMS Moodle for an effective implementation of an innovative policy in higher educational institutions. International Journal of Emerging Technologies in Learning (IJET), 15(13): 172-189. https://doi.org/10.3991/ijet.v15i13.14945

[17] Martín-Blas, T.; Serrano-Fernández, A. (2009). The role of new technologies in the learning process: Moodle as a teaching tool in Physics. Comput. Educ., 52: 35-44. https://doi.org/10.1016/j.compedu.2008.06.005

[18] Lukianenko, V., \& Vadaska, S. (2020). Evaluating the efficiency of online English course for first-year engineering students. Revista Romaneasca pentru Educatie Multidimensionala, 12(2) (Sup1): 62-69. https://doi.org/10.18662/rrem/12. 2sup1/290

[19] Avramescu, E. T. (2017). Management of online learning platforms in medical education. In E.Soare \& C.Langa (Eds.), The European proceedings of social andbehavioural sciences (pp.1559-1569). https://doi.org/10.15405/epsbs.2017.05.02.

[20] Peerapolchaikul, T., Suealek, N., \& Rojpibulstit, P. (2019). Students' attitudes towards the effectiveness of Moodle platform at preclinical-medical level in PBL curriculum. Studies in Logic, Grammar and Rhetoric, 60(1): 61-74. https://doi.org/10.2478/slgr-2019-0045

[21] Garrison, D. R., Anderson, T., \& Archer, W. (1999). Critical inquiry in a text-based environment: Computer conferencing in higher education model. The Internet and Higher Education, 2(2-3): 87-105. https://doi.org/10.1016/s1096-7516(00)00016-6

[22] Kent, A.M. \& Simpson, J.L. (2010). Interactive videoconferencing. Journal of Digital Learning in Teacher Education 27 (1): 12-21.https://doi.org/10.1080/21532974.2010. 10784652

[23] Reaburn, P., \& McDonald, J. (2017). Creating and facilitating communities of practice in higher education. In McDonald, Cater-Steel (Eds), Communities of Practice (pp.121-150). Singapore: Springer. https://doi.org/10.1007/978-981-10-2879-3_6

[24] Boatin, A., Ngonzi, J., Bradford, L., Wylie, B.J. (2015). Teaching by teleconference: a model for distance medical education across two continents. Open Journal of Obstetrics and Gynecology, 05(13): 754-761. https://doi.org/10.4236/ojog.2015. 513106

[25] Lavrysh, Y. (2016). Peer and self-assessment at ESP classes: case study. Advanced Education, 6: 60-68. https://doi.org/10.20535/2410-8286.85351

[26] Fischer, A.J., Collier-Meek,M.A., Bloomfield, B., Erchul, W.P., \& Gresham, F.M. (2017). A comparison of problem identification interviews conducted face-to-face and via videoconferencing using the consultation analysis record. Journal School Psychology, 63: 6376. https://doi.org/10.1016/j.jsp.2017.03.009

[27] Mukan, N., \& Lavrysh, Y. (2020). Video conferencing integration: challenges and opportunities at universities. Revista Romaneasca Pentru Educatie Multi dimensionala, 12(1Sup2): 108-114. https://doi.org/10.18662/rrem/12.1sup2/253

[28] S.A.G.E.S The Society of American Gastrointestinal and Endoscopic Surgeons (January 2009) Guidelines for the surgical practice of telemedicine; practice/clinical guidelines. http://www.sages.org/publication/id/21.https://doi.org/10.1007/s004640000290

[29] Augestad, K.M., \& Lindsetmo, R.O. (2009). Overcoming Distance: Video-Conferencing as a Clinical and Educational Tool Among Surgeons. World J Surg, 33: 1356-1365. https://doi.org/10.1007/s00268-009-0036-0 
[30] Önöral, Ö., \& Kurtulmus-Yilmaz, S. (2020). Influence of covid-19 pandemic on dental education in Cyprus: preclinical and clinical implications with e-learning strategies. Advanced Education, 7(16): 69-77. https://doi.org/10.20535/2410-8286.212792

[31] Kichula, M., Oleksii, K., \& Korolova, T. (2019). Evaluating professional qualities of medical students. Advanced Education, 6(13): 44-53. https://doi.org/10.20535/2410$\underline{8286.154723}$

[32] [32] Zheng, T., \& Zhu, X. (2020). Comparing the effects of online teaching during the COVID-19 pandemic and traditional teaching in Surgical Nursing. BMC Nurcing. Preprint article. https://doi.org/10.21203/rs.3.rs-108407/v1

[33] Ehrlich, H., McKenney, M., \& Elkbuli, A. (2020). We asked the experts: virtual learning in surgical education during the COVID-19 pandemic-shaping the future of surgical education and training. World journal of surgery, 44(7): 2053-2055. https://doi.org/10.1007/ $\underline{\mathrm{s} 00268-020-05574-3}$

[34] Khan, K. S., Keay, R., McLellan, M., \& Mahmud, S. (2020). Impact of the COVID-19 pandemic on core surgical training. Scottish Medical Journal, 65(4): 133-137. https://doi.org/10.1177/0036933020949217

[35] Dennis, C. (2020). Online learning communities and flexibility in learning. In Chris Dennis, Stuart Abbott, Ruth Matheson, and Sue Tangney (eds.), Flexibility and Pedagogy in Higher Education (pp.193-197). Brill Sense. https://doi.org/10.1163/9789004438118

[36] Isayeva, O., Shumylo, M., Khmilyar, I., Mylyk, O., \& Myskiv, I. (2020). Blended learning in higher medical education: principles and strategies of teaching foreign languages. Advanced Education, 7(14): 11-18. https://doi.org/10.20535/2410-8286.183725

[37] Woodcock, S., Sisco, A. \& Eady, M. J. (2015). The learning experience: training teachers using online synchronous environments. Journal of Educational Research and Practice, 5 (1): 21-34. https://doi.org/10.5590/jerap.2015.05.1.02

[38] Adedoyin, O.B. \& Soykan, E. (2020). Covid-19 pandemic and online learning: the challenges and opportunities. Interactive Learning Environments: 1-13. https://doi.org/10. $\underline{1080 / 10494820.2020 .1813180}$

[39] Kalay, D., Fedorenko, S., Guryeyeva, L., \& Kolomiiets, S. (2020). Forming students' terminological competence in the MOODLE-based E-learning course. Advanced Education, 7(16): 104-111. https://doi.org/10.20535/2410-8286.216980

[40] Spante, M., Sofkova, S., Hashemi, M. L., Lundin, M. \& Algers, A. (2018). Digital competence and digital literacy in higher education research: Systematic review of concept use. Cogent Education, 5(1). https://doi.org/10.1080/2331186x. 2018.1519143

[41] Fatani, T.H. (2020). Student satisfaction with videoconferencing teaching quality during the COVID-19 pandemic. BMC Med Educ 20, 396. https://doi.org/10. 1186/s12909-020$\underline{02310-2}$

[42] Srivastava, V., Pandey, V., Tiwari, P. et al. (2020). Utility of real-time online teaching during COVID era among surgery postgraduates. Indian J Surg, 82: 762-768. https://doi.org/10.1007/s12262-020-02592-2

[43] Melnyk, V., \& Mikhnenko, G. (2020). International students' perception of teaching microbiology, virology and immunology at medical universities in Ukraine. Advanced Education, 7(15): 56-65. https://doi.org/10.20535/2410-8286.201734

[44] Saienko, N., \& Lavrysh, Y. (2020). Mobile assisted learning for self-directed learning development at technical university: SWOT analysis. Universal Journal of Educational Research, 8(4): 1466-1474. https://doi.org/10.13189/ujer.2020.080440

[45] Lytovchenko, I., \& Voronina, H. (2020). MOOC as remote ESP learning tool at university in quarantine: focus on students' attitudes. Revista Romaneasca Pentru Educatie Multidimensionala, 12(2Sup1): 70-76. https://doi.org/10.18662/rrem/12.2sup1/291 
[46] Tekkol, I.A., and Demirel, M. (2018). An investigation of self-directed learning skills of undergraduate students. Front. Psychol.,9. https://doi.org/10.3389/fpsyg. 2018.02324

[47] Sheela, D., Sandhya, B.K, Ramya, S R, Ravichandran, K, \& Reba, K. (2016). Self-directed learning to enhance active learning among the 2nd-year undergraduate medical students in Microbiology: An experimental study. Journal of current research in scientific medicine, 2(2): 80-83. https://doi.org/10.4103/2455-3069.198379

[48] Hartnett, M. (2016). The importance of motivation in online learning. In: Motivation in Online Education (pp.5-32). Springer, Singapore. https://doi.org/10.1007/978-981-10$\underline{0700-2 \_2}$

[49] Ferrer, J., Ringer, A., Saville, K., A Parris, M., \& Kashi, K. (2020). Students' motivation and engagement in higher education: the importance of attitude to online learning. Higher Education. https://doi.org/10.1007/s10734-020-00657-5

[50] Guo, W. (2020). Psychological problems of chinese college students under the Covid-19 epidemic and the countermeasures. Learning \& Education, 9 (1): 5. https://doi.org/10. $\underline{18282 / 1-\mathrm{e} . \mathrm{v} 9 \mathrm{i} 1.870}$

[51] Yadav, A.K. (2020). Impact of Online Teaching on Students' Education and Health in India during the Pandemic of COVID-19 (E-pub Ahead of Print). Coronaviruses. https://doi.org/10.2174/2666796701999201005212801

[52] Saputra, M.D., Joyoatmojo, S., Wardani, D.K., \& Sangka, K. (2019). Developing criticalthinking skills through the collaboration of Jigsaw Model with Problem-Based Learning Model. 2019International Journal of Instruction 12(1): 1077-1094. https://doi.org/10. 29333/iji.2019.12169a

[53] McLean, S. F. (2016). Case-based learning and its application in medical and health-care fields: a review of worldwide literature. Journal of Medical Education and Curricular Development, 3: JMECD.S20377. https://doi.org/10.4137/jmecd

[54] Wilcha, R.J. (2020). Effectiveness of virtual medical teaching during the COVID-19 crisis: systematic review. JMIR Med Educ, 6(2): e20963. PMID: 33106227; PMCID: PMC7682786. https://doi.org/10.2196/20963

\section{Authors}

Anatolii Levitskyi is Doctor of Medicine, Professor, Honored Doctor of Ukraine, Head of the Department of Pediatric Surgery at Bogomolets National Medical University, Kyiv, Ukraine. 01601, T. Shevchenko boulevard, 13. Took internships in pediatric traumatology, orthopedics and vertebrology at the universities in the USA, Germany, the Netherlands, Israel, Turkey, the Czech Republic, Poland. In 1998 he defended doctoral dissertation on "Surgical treatment of funnel-shaped chest deformities in children." Scientific interests: conservative and surgical treatment of injuries, congenital and acquired orthopedic diseases, spinal deformities and group cells in children and adolescents. Author of 257 scientific papers, co-author of 7 monographs, 9 manuals, 4 unified clinical protocols, 19 patents for inventions. Expert of the Ministry of Health of Ukraine on orthopedics and traumatology. Full member of the Scoliosis Research Society (SRS), Conservative Management of Spinal Deformities (SOSORT), International Society for Minimal Intervention in Spinal Surgery (ISSMISS), academic community for innovative education and research in spine care, inspiring lifelong learning and improving patients' lives (AOSPINE), Association of 
Orthopedic Traumatologists of Ukraine, Pediatric Surgeons of Ukraine, President of the Association of Pediatric Orthopedists-Traumatologists of Ukraine.

Iryna Benzar is Doctor of Medicine, Professor of the Department of Pediatric Surgery at Bogomolets National Medical University, Kyiv, Ukraine. In 2018 she defended doctoral dissertation on the topic: "Diagnosis and tactics of surgical treatment of vascular anomalies in children." The author of more than 100 scientific publications, co-author of five textbooks, the monograph "Vascular anomalies in children". Took an internship at the Vascular Anomalies Center (VAC) at Boston Children's Hospital (2015) and the Vascular Institute of New York (2019). Full member of the International Society for the Study of Vascular Anomalies (ISSVA) since 2015 and a member of the All-Ukrainian Association of Pediatric Surgeons. Main research interests are the study of surgical, endovascular and conservative treatment of vascular abnormalities (vascular tumors and vascular malformations). Introduced into practice modern methods of treatment of vascular tumors and vascular malformations.

Volodymyr Vitiaz is Assistant Professor of the Department of Pediatric Surgery at Bogomolets National Medical University, Kyiv, Ukraine. In 2010 he defended dissertation on "Osteosynthesis of fractures7 of the proximal radial bone in children." Completed an internship of 4 months in Japan in 2004 and an internship in the United States at a clinic at the University of Mississippi in 2008. Member of the European Association of Pediatric Orthopedists. Publications: a co-author of 3 textbooks, 17 scientific papers and 1 patent in Ukraine. A pediatric orthopedist of the highest category. Specialization: treatment of injuries and deformities of the skeleton in children, arthroscopic interventions in children, reconstructive interventions on the hip joint.

Dmytro Golovatiuk is Candidate of Medical Sciences, Assistant Professor, of the Department of Pediatric Surgery at Bogomolets National Medical University, Kyiv, Ukraine. In 2014 he defended dissertation on "Diagnosis and treatment of bone cysts in children." Number of publications - 18. Co-author of 1 textbook on pediatric surgery, 1 textbook on pediatric orthopedics. Co-author of 3 patents in Ukraine. Coauthor of adapted clinical guidelines and a unified clinical protocol for the diagnosis and treatment of hip dysplasia and congenital hip dislocation in children. Research interests: conservative and surgical treatment of musculoskeletal injuries in children, conservative and surgical treatment of congenital hip dislocation and hip dysplasia, treatment of benign tumors and tumor-like formations of the musculoskeletal system in children. Member of the European Paediatric Orthopaedic Society (EPOS). Email: dvgolovatuk@gmail.com

Oleksandr V. Karabenyuk is Candidate of Medical Sciences, Assistant Professor, of the Department of Pediatric Surgery at Bogomolets National Medical University, Kyiv, Ukraine. The topic of $\mathrm{PhD}$ dissertation is "The use of ultrasound diagnostics and low-intensity infrared laser therapy for injuries in the elbow joint in children." Research interests: elbow injury, congenital clubfoot, polytrauma. The author of 15 publications: textbooks - 1, guidelines - 3, inventions - 3, rational proposals - 3. Secretary of the Public Organization "All-Ukrainian Association of Pediatric OrthopedistsTraumatologists".

Article submitted 2021-02-15. Resubmitted 2021-03-26. Final acceptance 2021-03-27. Final version published as submitted by the authors. 